DOI:10.22337/2587-9618-2018-14-१-१००-१००

\title{
NON-RIGID KINEMATIC EXCITATION FOR MULTIPLY-SUPPORTED SYSTEM WITH HOMOGENEOUS DAMPING
}

\author{
Alexander G. Tyapin \\ JSC “Atomenergoproject”, Moscow, RUSSIA
}

\begin{abstract}
This paper continues the discussion of linear equations of motion. The author considers non-rigid kinematic excitation for multiply-supported system leading to the deformations in quasi-static response. It turns out that in the equation of motion written down for relative displacements (relative displacements are defined as absolute displacements minus quasi-static response) the contribution of the internal damping to the load in some cases may be zero (like it was for rigid kinematical excitation). For this effect the system under consideration must have homogeneous damping. It is the often case, though not always. Zero contribution of the internal damping to the load is different in origin for rigid and non-rigid kinematic excitation: in the former case nodal loads in the quasi-static response are zero for each element; in the latter case nodal loads in elements are non-zero, but in each node they are balanced giving zero resulting nodal loads. Thus, damping in the quasi-static response does not impact relative motion, but impacts the resulting internal forces. The implementation of the Rayleigh damping model for the right-hand part of the equation leads to the error (like for rigid kinematic excitation), as damping in the Rayleigh model is not really "internal": due to the participation of mass matrix it works on rigid displacements, which is impossible for internal damping.
\end{abstract}

Keywords: seismic response, Rayleigh damping model, multiply-supported systems

\section{НЕЖЕСТКОЕ КИНЕМАТИЧЕСКОЕ ВОЗДЕЙСТВИЕ ДЛЯ МНОГООПОРНОЙ СИСТЕМЫ С ОДНОРОДНЫМ ДЕМПФИРОВАНИЕМ}

\author{
А.Г. Тяпин \\ $\mathrm{AO}$ «Атомэнергопроект», г. Москва, РОССИЯ
}

\begin{abstract}
Аннотация: В настоящей статье продолжается ранее начатое обсуждение вопросов вывода уравнений движения для линейных расчетов сооружений на динамические воздействия. Автор рассматривает «нежесткое» движение опор многоопорной системы, порождающее деформации уже в квазистатической реакции. Оказывается, что в уравнениях движения, записанных в относительных перемещениях (относительные перемещения определяются как абсолютные перемещения за вычетом квазистатической реакции), вклад матрицы внутреннего демпфирования в нагрузку может оказаться равным нулю даже для «нежесткого» смещения опор, - подобно тому, как это было показано ранее для «жесткого» смещения опор. Однако для этого рассматриваемая система должна быть однородной по демпфированию. Такая ситуация на практике встречается часто, хотя и не всегда. Между нулевым вкладом матрицы демпфирования в нагрузки в случаях «жесткого» и «нежесткого» движения опор для однородной по демпфированию системы есть принципиальная разница: в первом случае в квазистатической реакции соответствующие узловые силы равны нулю в каждом элементе, а во втором случае в деформированных элементах появляются усилия, но в узлах их суммы равны нулю. Демпфирование, связанное с квазистатической реакцией, не повлияет на относительные перемещения, но проявится при вычислении полных внутренних усилий. Использование модели демпфирования Рэлея для правой части уравнения движения, как и в случае «жесткого» кинематического возбуждения опор, приводит к ошибочным результатам, поскольку демпфирование в модели Рэлея благодаря участию матрицы масс работает на жестких смещениях системы, в отличие от внутреннего демпфирования.
\end{abstract}

Ключевые слова: сейсмическая реакция, модель демпфирования Рэлея, многоопорные системы 
Discussion about damping at forming of seismic loadings piques interest of civil engineers $[1,2]$. There are some disagreements about internal damping at right part of movement equation, written in the relative displacement form for multi-supported system. At the same time, author wrote about case of "rigid" support movement of multi-supports systems in the previous papers. It should be specified, that "rigid" movement of some points row is not equivalent of equal forward movement of such points, that can be considered as only partial case. "Rigid" movement of some points row means that one's move as it "frozen" into absolutely rigid solid body. If this solid body rotates, then forward movement of some points of such body in local coordinate systems, linked with these points, differs in accordance with it coordinate. At the same time, such movement remains "rigid".

Principle feature of system behavior at "rigid" movement of supports is that quasi static response to such movement is "rigid" too. In other words, at quasi static response not only support but all points of system move "rigidly". At the same time, there are not displacement in system, therefore internal forces, caused by system rigid and damping, don't appear. This aspect does not depend on a type and homogeneous of internal damping as well as rigidity distribution in a system. Consequently, dividing movement of linear system to translational motion of whole system with it supports and additional movement of each point relative to supports, it appears that right part of movement equation contains only inertia forces. There are not rigidities or damping components in the right part of equation.

After the paper [2] publication, some authors proposed to observe alternative case, when supports movement is not "rigid". In the paper [2], respective designations and equations are introduced for such movement.

Turning to terminology, as it seems to the author, the "translational motion" badly corresponds to description of quasi static responses in similar system, since system responses includes displacements at "non-rigid" motion of supports. It already is not "translational motion", as it is at "rigid" motion of supports. Therefore, let us to present absolute displacements $U$ as sum of quasi static response $R$ and relative displacements $X$. Top index " + " means that it is observed whole columns, including support displacements; missing of this index means that it is observed reduced columns, which includes displacements of all points, excepting supports. Respectively, matrixes with such index and without it take different orders. Let us rewrite equation (10), taken from the paper [2], in the relative displacements form:

$$
\begin{aligned}
& {[M][\ddot{X}(t)]+[C][\dot{X}(t)]+[K][X(t)]=} \\
& \quad=-\left([M][T]+\left[M_{s b}\right]\right)\left[\ddot{R}_{b}\right]-\left([C][T]+\left[C_{s b}\right]\right)\left[\dot{R}_{b}\right]
\end{aligned}
$$

Here $[M],[K]$ and $[C]$ are block matrices of inertia, stiffness and viscous damping, corresponding to all system nodes, excepting supports; $\left[M_{s b}\right]$ and $\left[C_{s b}\right]$ are block matrices of inertia and viscous damping, which link supports and non-support nodes; $\left[R_{b}\right]$ is column of support displacements; $[T]$ is matrix, linking quasi static response of non-support nodes with support displacement:

$$
[R]=[T]\left[R_{b}\right] ; \quad[T]=-[K]^{-1}\left[K_{s b}\right]
$$

Where $\left[K_{s b}\right]$ is block matrix of stiffness, that links non-support nodes with support nodes. Thus, conclusion of previous paper [2] can be formulated in the following form: if matrices $[C]$ and $\left[C_{s b}\right]$ describes internal damping correctly, hen at either rigid displacement of supports $\left[R_{b}\right]$ the last member in the right part of (1) equals to zero. It is should be noted ones more time, that this conclusion doesn't require homogeneous damping or another special links between damping and stiffness of a system.

Current paper describes non-rigid displacement of supports $\left[R_{b}\right]$. Let us pay attention that second formula from (2) leads to relationship

$$
[K][T]+\left[K_{s b}\right]=0 .
$$


Comparing the left part of (3) with first multiplier at the last addend in the right part of (1), we can conclude, if viscous damping matrix $\left[\mathrm{C}^{+}\right]$is proportional to stiffness matrix $\left[\mathrm{K}^{+}\right]$in partial case, then first multiplier at the last addend in the right part of (1) equals to zero. Respectively, last addend in the right side of formula (1) equals to zero at support motion or without it. It was paid attention by V.A. Semenov, speaking about proportionality between damping and stiffness.

First of all, such proportionality between damping and stiffness may appears when material of system is homogeneous by damping properties, for example, physically homogeneous, when structure made of steel or reinforced concrete only and loadings don't exceed ultimate values. As it shows by experiments, damping of construction material is not viscous, but plastic or hysteresis or material by Sorokin model. In frequencies range, the real values of elastic modulus are substituted by complex values, where imaginary parts of complex modulus don't depend on the frequency and proportional to real parts. Homogeneous damping means in this case, that proportion coefficients between real and imaginary parts of complex modulus are the same for all materials of system. It is very frequent situation, and conclusion about zero damping at right part of motion equation, written in the form of relative displacements, stay actual. Remark about material work at nonultimate states is made, because effective modulus and effective damping are changed at large deformations. Here large deformations are not connected with geometric non-linearity, since it is described by equivalent linear models $[3,4]$. If all elements are loaded by the same loads, then at deformation closing to ultimate values the homogeneous damping remains actual. However, it may occur situations, when in the system ones' structures are closer to ultimate state than other. In this case the effective damping may differs in different structures at the same material.

Thus, in a system with homogeneous damping even at non-rigid motion of supports the last member of right part of motion equation (1) equals to zero. At first sight, such result is analogous to results, obtained before for rigid motion of supports [2], however these results have principle physical difference. Physical meaning of each addend in equation (1) is nodal forces. In accordance with assembling rules of stiffness and damping matrices in FEM for chosen node these nodal forces can be spread out to force sum, coming in the node from finite elements, linked with this node. The resultant nodal force, determined by stiffness matrix or damping matrix may be null matrix by two reasons: 1) all members, determining by separate multipliers are equal to zero; 2) members are not null, but it sum equal to zero at special situation.

At "rigid" motion of supports the first reason executes. Quasi static response is rigid for entire system as well as for each finite element, therefore nodal forces, linked with stiffness and internal damping at each element are equal to zero. Respectively, resultant nodal forces at arbitrary node are equal to zero.

At "non-rigid" motion of supports the second reason exacts. Finite elements at quasi-static response are deformed, and internal forces appear, that leads to nonzero values of nodal forces. This fact relates not only with stiffness, but damping. As result, integral nodal forces at right part of equation (1) for each node, as it is shown before, are equal to zero, but such result is reached by addition of nonzero members.

Is it mean that damping, linked with quasi static response, disappears from system? No, it is. Let us remember, that equation (1) allows to determinate just relative displacement, velocities and accelerations. It should be noted, that determination of "relative" internal forces linked not only with stiffness, but also damping member in the left part of equation (1). However, these "relative" internal forces must be added to forces, caused by quasi static response, to determinate resultant dynamic internal forces. At "rigid" motion of supports forces, caused by quasi static response, are equal to zero. And here stiffness and damping, working at quasi static displacements and velocities, are applied at qua- 
si static force calculation. Thus, part of damping, linked with quasi static response, influence to resultant forces in a system, though it occurs without "relative" part.

Now let us to discuss some questions of computational practice. Physical hysteresis damping in material forcedly substitute by non-physical damping that is proportional to velocity, using Rayleigh model, to save traditional form of differential motion equations:

$$
\left[C^{+}\right]=\alpha\left[M^{+}\right]+\beta\left[K^{+}\right]
$$

It was already written about approximate and non-physical aspect of such substitution. First member of right part of equation (4) describes not internal, but external damping and works even at rigid displacements, that is principally impossible at internal damping. This member is introduced into Rayleigh model just to approximate restore constancy of modal factors of damping by frequency. Such constancy by frequency is observed in experiments and appears as natural consequence of plastic damping nature. This constancy disappears at introducing of viscous damping instead of plastic damping. It is necessary to apply non-physical substitution to approximate restoration.

In this case, appliance of Rayleigh model can be recognized as traditionally justified for damping matrix. But at right part of (1) in comparison with left part the modal factors of damping are unimportant. If we exclude non-physical first member of Rayleigh model from right part of the equation (1), then remaining second member that proportional to stiffness matrix in accordance with relationship (3) leads to written before right result, that is to disappearance of damping from right part of motion equation, written in the form of relative displacements for system with homogeneous damping.

In this case ultimate transformation, that was destructured by applying of full Rayleigh model (4), which is used at the right part of motion equation. Really, in accordance with physics, "rigid" motion of supports can be described as partial case of "non-rigid" motion. Respectively, equations of "non-rigid" motion of supports should be transformed to equations of "rigid" motion in this case. However non-physical first member of the relationship (4) at right part of (1) interrupts such transformation, because it does not disappear at "rigid" motion of supports. If we exclude this member from right part of the equation, ultimate transformation restores.

Let us discuss consequences of damping member disappearing at right part of equation (1) in the case of system with homogeneous damping conditions. The right part of equation (1) is simplified and takes the form:

$$
\begin{aligned}
& {[M][\ddot{X}(t)]+[C][\dot{X}(t)]+[K][X(t)]=} \\
& =-\left([M][T]+\left[M_{s b}\right]\left[\ddot{R}_{b}\right]\right.
\end{aligned}
$$

The form of this equation is like a traditional equation of "rigid" displacement of supports, that allows expect that traditional linear spectral approach is applicable in this case. But there are two reasons that can break up such expectations. At first, as it is shown before, quasi static response at "non-rigid" displacements of supports makes a contribution to resultant internal forces. Thus, "relative" forces, calculated by equation (5) using analog of linear spectral method, should be added to "quasi static" forces, caused by stiffness as well as damping. There are suggestions of such addition. For example, it is supposed to use approach connected with square root of the sum of squares (SRSS) as it is contained in the codes of nuclear industry [3].

At second, at transformation of equation (5) to equations of the modal method, that is the basis of the linear spectral approach, the difficulties appear with right part of equation (1), and it left part stays traditional. At "rigid" motion of supports quasi static response $\mathrm{R}$, determined by relation (2), is "rigid". Contribution of each mode to resultant force at impact acting during chosen direction is determined by so called "involvement factor" of this mode through reviewed direction. Since there are six directions of "rigid" impact, then only six "involvement factors" are applied for each mode. Such coefficients are 
generated by majority of computational programs as part of standard report at modal analysis.

At "non-rigid" motion of supports mode involvement factors, taken by quasi static responses, substitute involvement factors, taken by impact's directions, at right parts of modal motion equations. For example, if supports displacements $\left[R_{b k}\right]$ are correspond to initial seismic impact through the $\mathrm{k}$ direction, then modal force $q_{j k}$ for $j$-th mode $\left[\varphi_{j}\right]$ is described by ana$\log$ of involvement factor:

$$
q_{j k}=-[\varphi]^{T}\left([M][T]+\left[M_{s b}\right]\right)\left[\ddot{R}_{b k}\right]
$$

First two multipliers at right part of (6) are similar to multipliers at traditional involvement factor of $j$-th mode for arbitrary direction from six directions of "rigid" impact, however third multiplier differs from first ones. Additional problem is that "non-rigid" displacements of supports $\left[R_{b k}\right]$ may depend on the frequency or wavelength, that is equivalent to first one. This aspect makes practical calculations of modal force more difficult.

Codes of nuclear industry [1] contains a few techniques to calculate inertia forces of multi supported system by spectral method. All of these methods are approximate and it accuracy significantly depends on the static correlation of impact at different supports.

Now let us refuse to suggestion about homogeneous damping and observe widely distributed partial situation when damping is heterogeneous. This situation occurs, when system with homogeneous damping supplemented by viscous dampers. Typical sample is the reinforced concrete building, built on "foundation suspension" including "foundation dampers". This approach is frequently applied into platform models of "structure - foundation" systems [5].

The first that should be noted is that quasi static response of such system is similar to system before additional dampers appearance. The second note is that the damping matrix of such system consists of matrix of homogeneous damping and matrices of additional dampers. Consequently "homogeneous" damping disappear from right part of the motion equation, as it was before, but damping members corresponding to additional dampers are saved at the right part.

When "ground springs" are used together with ground dampers the viscous of ground dampers should be divided into two parts. The first part corresponds to "homogeneous damping" in structure and it is determined using $\beta$ coefficient from equation (4), obtained for structure, fastened to rigid ground spring. And remaining viscous of ground damper is additional and remains at right part of the motion equation.

Conclusions. Initial conclusion about dumping members' disappearance from the right part of the motion equation is spread to "non-rigid" motion of supports at system with homogeneous damping from "rigid" motion of supports in multi supported systems. It is noted that damping, linked with quasi static response of system to "non-rigid" motion of supports, does not disappear entirely in this case. It influence to results at calculation of internal forces. "Homogeneous" member disappears from the right part of the motion equation at using additional dampers in homogeneous system (for example at foundation suspension of platform models), but "additional" member remains there.

\section{REFERENCES}

1. Tyapin A.G. O Roli Dempfirovaniya $v$ Dinamicheskikh Nagruzkakh v Raschetakh na Seysmicheskiye Vozdeystviya [About Damping Influence to Dynamic Loadings at Calculation to Seismic Impacts]. // Seysmostoykoye stroitel'stvo. Bezopasnost' sooruzheniy, 2018, No. 1, pp. 33-39.

2. Tyapin A.G. Zhestkoye i Nezhestkoye Kinematicheskoye Vozdeystviye Dlya Mnogoopornoy Sistemy: Yeshche Raz o Roli Dempfirovaniya v Dinamicheskikh Nagruzkakh pri Raschete na Seysmicheskiye Vozdeystviya [Rigid and Non-Rigid Kinematic Impact to Multi-Supported System: One More Time About Damping Influence to Dynamic Loadings at Calculation 
to Seismic Impacts] // International Journal for Computational Civil and Structural Engineering, 2018, Vol. 14, Issue 1, pp. 164170.

3. Seismic Analysis of Safety-Related Nuclear Structures and Commentary. ASCE4-98. Reston, Virginia, USA. 1999.

4. Seismic Analysis of Safety-Related Nuclear Structures and Commentary. ASCE/SEI 416. Reston, Virginia, USA. 2017.

5. Tyapin A.G. Platformennyye Modeli v Zadachakh Ucheta Vzaimodeystviya Sooruzheniy s Osnovaniyem pri Raschetakh na Seysmicheskiye Vozdeystviya: Nauchnoye izdaniye [Platform Models in Problems Deals With Accounting Structure - Foundation Interaction at Calculation to Seismic Loads]. Moscow, ASV Publishing House, 2015, 208 pages.

\section{СПИСОК ЛИТЕРАТУРЫ}

1. Тяпин А.Г. О роли демпфирования в динамических нагрузках в расчетах на сейсмические воздействия. // Сейсмостойкое строительство. Безопасность сооружений, 2018, №1, с. 33-39

2. Тяпин А.Г. Жесткое и нежесткое кинематическое воздействие для многоопорной системы: еще раз о роли демпфирования в динамических нагрузках при расчете на сейсмические воздействия. // International Journal for Computational Civil and Structural Engineering, 2018, Vol. 14, Issue 1, c. 164-170.

3. Seismic Analysis of Safety-Related Nuclear Structures and Commentary. ASCE4-98. Reston, Virginia, USA. 1999.

4. Seismic Analysis of Safety-Related Nuclear Structures and Commentary. ASCE/SEI 416. Reston, Virginia, USA. 2017.

5. Тяпин А.Г. Платформенные модели в задачах учета взаимодействия сооружений с основанием при расчетах на сейсмические воздействия. - М.: Издательство АСВ, 2015. - 208 с.
Alexander G. Tyapin, Dr.Sc., Chief Specialist, JSC "Atomenergoproject"; 1-119, Slavyansky Bulvar, Moscow, 121352, Russia; phone +7(985)998-33-21;

E-mail: atyapin@bvcp.ru.

Тяпин Александр Георгиевич, доктор технических наук; главный специалист АО «Атомэнергопроект», Россия, 121352, Москва, Славянский бульвар, 1-119, тел.+7(985)998-33-21, e-mail: atyapin@ bvcp.ru. 